\title{
TRANSCRIÇÃO DE GENES DE PROTEÍNAS DE MEMBRANA DE ISOLADOS BRASILEIROS DE Anaplasma marginale
}

\author{
CARLOS A.N. RAMOS ${ }^{1}$; FLÁBIO R. ARAÚJO²; ANA L.A.R. OSÓRIOํㅜㅇ CLÁUDIO R. MADRUGA²; \\ GRÁCIA M. S. ROSINHA²; CLEBER O. SOARES²; CARINA ELISEI ${ }^{3}$
}

\begin{abstract}
RAMOS, C.A.N.; ARAÚJO, F.R.; OSÓRIO, A.L.A.R.; MADRUGA, C.R., ROSINHA, G.M.S.; SOARES, C.O.; ELISEI, C. [Transcription of genes of membrane proteins of Brazilians isolates of Anaplasma marginale].Transcrição de genes de proteínas de membrana de isolados brasileiros de Anaplasma marginale. Revista Brasileira de Parasitologia Veterinária, v. 16, n. 3, p. 152-155, 2007. Embrapa Gado de Corte, BR 262, Km 04, Caixa postal 154; Campo Grande, MS 79002-970. Brazil. E-mail: flabio@cnpgc.embrapa.br

This work shows the transcription profile of membrane protein genes in three Brazilian isolates of Anaplasma marginale (Rio Grande do Norte, Pernambuco-Zona da Mata, and Pernambuco-Sertão). RNA was purified from cattle blood experimentally-infected with the three isolates of $A$. marginale. After reverse transcription, genes omp1, 2, 3, 4, 5, 7, 8, 9, 10, 11, 12, 13, and 14; opag1-3; virB3, 9, and 10; am097, 197, 254, 854, and 956 were amplified by PCR, with specific primers. Transcripts were detected for all genes, except omp2, 3 e opag3 in all isolates and for omp7 in one out of the three isolates analyzed. Absence of transcription for opag3 and omp7 diverge from the North American isolates of $A$. marginale. Reasons for such differences were discussed.
\end{abstract}

KEY WORDS: Transcription, OMPs, RT-PCR, Anaplasma marginale, Brazil.

\section{RESUMO}

Este trabalho demonstra o padrão de transcrição de genes de proteínas de membrana em três isolados brasileiros de $A$. marginale (Rio Grande do Norte, Pernambuco-Zona da Mata e Pernambuco-Sertão). O RNA foi purificado a partir de sangue de bovinos infectados experimentalmente com os três isolados de A. marginale. Após transcrição reversa, os genes omp1, 2, 3, 4, 5, 7, 8, 9, 10, 11, 12, 13 e 14; opag1-3; virB3, 9, 10; am097, 197, 254, 854 e 956 foram amplificados por PCR, com oligonucleotídeos iniciadores específicos. Detectaram-se transcritos para todos os genes analisados, exceto omp2, 3 e opag3 em todos os isolados e do gene omp7 em um dos isolados estudados. A ausência de transcrito para os genes opag3 e omp7 diverge do observado em isolados americanos da riquétsia. Possíveis razões para essas diferenças são discutidas.

PALAVRAS-CHAVE: Transcrição, OMPs, RT-PCR, Anaplasma marginale, Brasil.

${ }^{1}$ Programa de Pós-Graduação em Ciência Animal, Universidade Federal de Mato Grosso do Sul, Cidade Universitária, Caixa Postal 549, Campo Grande, MS 79070-900.

${ }^{2}$ Embrapa Gado de Corte, Setor de Sanidade Animal, BR 262, Km 04, Caixa Postal 154, Campo Grande, MS 79002-970, Brasil. E-mail: flabio@cnpgc.embrapa.br

${ }^{3}$ Bolsista de Desenvolvimento Científico Regional do CNPq/Fundect.

\section{INTRODUÇÃO}

A anaplasmose bovina, causada pela riquétsia Anaplasma marginale, é uma doença de grande importância econômica que é transmitida principalmente por carrapatos. A riquétsia infecta eritrócitos bovinos, causando severa anemia associada à anorexia, febre, diminuição no ganho de peso e produção de leite, e morte nos casos severos em animais não tratados (ZAUGG et al., 1985).

Estudos sobre resposta imune em animais protegidos contra anaplasmose indicam que a proteção está associada ao aumento da atividade fagocítica dos macrófagos induzida por interferongama (INF-g), interleucina-2 (IL-2), IL-12 e fator de necrose tumoral-alfa (TNF-), produzidos por linfócitos T CD4+, que ainda estimulam a produção de imunoglobulinas da subclasse IgG2 contra antígenos de superfície da riquétsia (McGUIRE et al., 1979; BROWN et al., 1998a, PALMER et al., 1999).

O recente seqüenciamento do genoma do isolado St. Maries de A. marginale possibilitou a identificação de 62 genes de proteínas de membrana previamente não conhecidas. A maioria desses genes foram classificados nas superfamílias msp1 ou msp2, e outros não foram associados a nenhuma superfamília (BRAYTON et al., 2005; BRAYTON et al., 2006). A superfamília msp2 foi criada em torno da seqüência dos genes de msp2, 3 e 4, que formam a base de uma família de antígenos de superfície denominada pfam 01617 (VIDOTTO et al., 1994; BATEMAN et al., 2004). O gene msp2 é transcrito como parte de um operon, no qual encontram-se 
genes associados denominados opags 1-3 (operon associated genes), os quais estão incluídos na família. Em opags 1-3, ocorre pequena variação durante o curso da infecção em mamíferos, ou entre diferentes isolados americanos da riquétsia (LÖHR et al., 2002). Ademais, 14 genes de proteínas de membrana externa (outer membrane proteins - OMPs) foram identificados com similaridades de seqüência com msp2 e msp4. Esses genes estão arranjados isoladamente ou em operons. Três desses genes (omp2, 3 e 6), podem ser pseudogenes, uma vez que não foram detectados transcritos no isolado St. Maries, todos os outros genes foram transcritos em eritrócitos bovinos infectados com o isolado St. Maries de A. marginale (NOH et al., 2006). Como os genes da superfamília msp2 são expressos na superfície bacteriana, o grau de conservação entre isolados de $A$. marginale emerge como uma importante questão. A imunização de bovinos com membrana externa induziu proteção contra a doença após desafio com A. marginale (TEBELE et al., 1991; BROWN et al., 1998a). Notavelmente, proteínas de membrana conservadas entre isolados são alvos para linfócitos T CD4+ provenientes de animais vacinados (BROWN et al., 1998b). Com isso, a identificação de proteínas de membrana altamente conservadas é uma prioridade para o desenvolvimento de vacinas contra anaplasmose.

Em isolados brasileiros de A. marginale é desconhecido se esses genes são transcritos ou expressos durante a infecção em hospedeiros mamíferos. Assim, o objetivo deste estudo foi verificar o padrão de transcrição desses genes em três isolados brasileiros da riquétsia.

\section{MATERIAL E MÉTODOS}

\section{Isolados de Anaplasma marginale}

Três bezerros Aberdeen Angus foram confirmados livres de A. marginale por PCR para msp5 e ELISA indireto para MSP1a e MSP2, conforme ARAÚJO et al. (2005). Os bezerros foram inoculados por via subcutânea com estabilizado criopreservado de eritrócitos infectados com isolados de A. marginale provenientes do Estado do Rio Grande do Norte (RN), e de duas microrregiões do estado de Pernambuco, designados Pernambuco - Zona da Mata (PE-ZM) e Pernambuco - Sertão (PE-SE). Os animais foram examinados diariamente para detecção de $A$. marginale por distensões sangüíneas coradas com Giemsa, e o volume globular médio também foi determinado. Para obtenção de altos níveis de riquetsemia, os bezerros foram imunosuprimidos com dexametasona. Por volta do $21^{\circ}$ dia pós-inoculação, os bezerros 0581 (isolado RN), 0583 (PE-ZM) e 0588 (PE-SE) apresentaram riquetsemias de 35, 87 e $20 \%$, respectivamente, quando então procedeu-se a coleta de sangue em tubos heparinizados para posterior extração de RNA total.

\section{Extração de RNA e reação da polimerase em cadeia após transcrição reversa (RT-PCR)}

A extração de RNA total foi realizada com Trizol Reagent (Invitrogen, EUA) conforme instruções do fabricante. O RNA extraído foi tratado com RQ1 Rnase - Free Dnase (Promega, EUA) por 30 minutos a $37^{\circ} \mathrm{C}$ seguido da inativação da enzima conforme instruções do fabricante. A transcrição reversa foi feita com sistema Impron II (Promega, EUA) utilizando como oligonucleotídeos iniciadores hexameros aleatórios, de acordo com as instruções do fabricante. A detecção de transcritos foi feita por PCR, utilizando-se oligonucleotídeos iniciadores específicos para os genes omp1, 2, 3, 4, 5, 7, 8, 9, 10, 11, 12, 13 e 14; opag1-3; virB3, 9, 10; am097, 197, 254, 854 e 956 (Tabela 1). As seqüências desses iniciadores foram submetidas ao programa Blastn (NCBI) para identificar seqüências homólogas em outros organismos relacionados e em outros genes de A. marginale.

Os parâmetros de amplificação foram 35 ciclos de desnaturação a $94^{\circ} \mathrm{C}$ por 1 minuto, anelamento a $60^{\circ} \mathrm{C}$ por 1 minuto para os genes omps1-14, opag2, 3 e virB3, e $55^{\circ} \mathrm{C}$ para opag1, virB9-10, am097, 197, 254, 854 e 956, e extensão a $72^{\circ} \mathrm{C}$ também por 1 minuto, seguida de uma etapa de extensão final a $72^{\circ} \mathrm{C}$ por 4 minutos. As reações de PCR foram realizadas a partir de DNA genômico, como controle positivo, cDNA para deteç̧ão de transcrito, e RNA total como controle negativo, de cada isolado da riquétsia. Os produtos das PCRs foram separados eletroforeticamente em agarose $1 \%$ e corados com brometo de etídio para visualização.

\section{RESULTADOS E DISCUSSÃO}

As seqüências dos iniciadores, utilizados nos estudo, quando submetidas ao programa Blastn (NCBI), não revelou identidade com escore significativo com outros organismos, sugerindo que os mesmos eram específicos para A. marginale.

O padrão de transcrição de genes de proteínas de membrana nos três isolados brasileiros de A. marginale está demonstrado na Figura 1. Não se observou transcrito para os genes omp2, 3 e opag3 em nenhum dos isolados analisados. Para o gene omp 7 , apenas no isolado PE-ZM não foi observado transcrito. Todos os outros genes apresentaram transcritos em todos os isolados analisados. As ausências de transcrito para os genes omp2 e 3 já havia sido descrita por NOH et al. (2006), sendo os dois, juntamente com o gene omp6, considerados como possíveis pseudogenes. Com relação ao gene opag3, sua transcrição e expressão já foram detectadas em eritrócitos infectados com diferentes isolados americanos de A. marginale (LÖHR et al., 2002) e em um isolado australiano (RIDING et al., 2003).

Alguns dos genes que apresentaram transcrito nos isolados brasileiros analisados (virb9 e 10, am097, 197, 254, 854 e 956) representam possivelmente uma importante fonte de antígenos para preparações vacinais, uma vez que, em estudo conduzido por LOPEZ et al. (2005), foram reconhecidos por IgG2 de bovinos imunizados com membrana de $A$. marginale. Ainda nesse estudo, duas dessas proteínas (Am197 e 854) descritas pela primeira vez em A. marginale, apresentaram identidade de seqüência com proteínas de Ehrlichia canis. Outras que se acreditava serem proteínas citoplasmáticas, como PepA (Am956) e EF-Tu (Am254), foram analisadas pelo programa TMHMM e reconhecidas como proteínas ancoradas à membrana externa e expostas no meio extracelular.

Possíveis explicações para ausência de transcritos em alguns genes de isolados brasileiros de $A$. marginale seria, con- 
forme sugerido por NOH et al. (2006), que omp2 e 3 são realmente pseudogenes. No caso de opag3 (todos os isolados analisados) e omp7 (no isolado PE-ZM), os níveis de transcrição poderiam ocorrer em níveis muito baixos, não sendo possível detectá-los com a técnica de RT-PCR. A transcrição desses genes poderia ocorrer também apenas em sítios específicos de multiplicação da bactéria, como nos tecidos dos hospedeiros invertebrados, o que não foi o objetivo desse estudo.

A evolução da bactéria com seus hospedeiros invertebrados poderia sugerir também uma possível explicação para as dife-

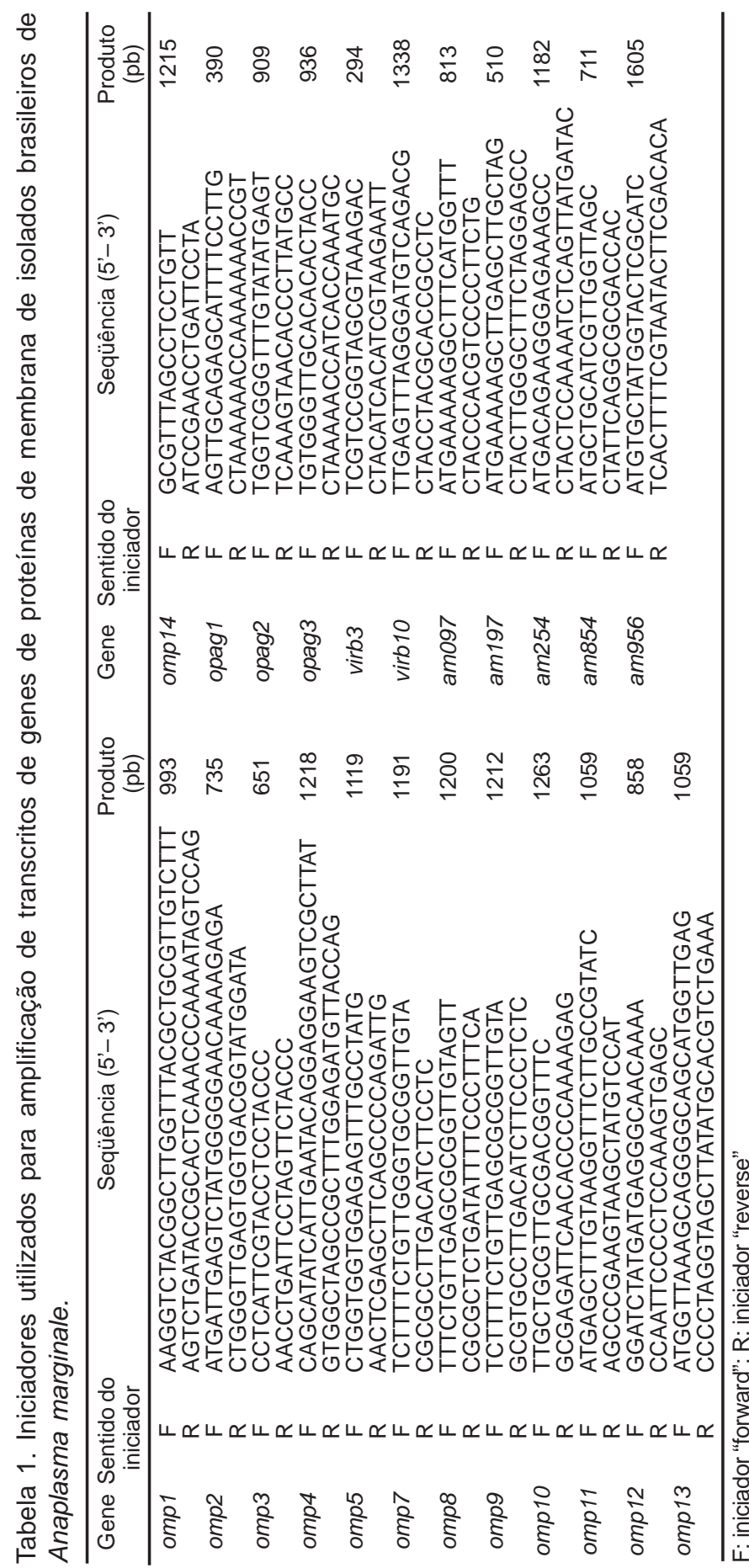

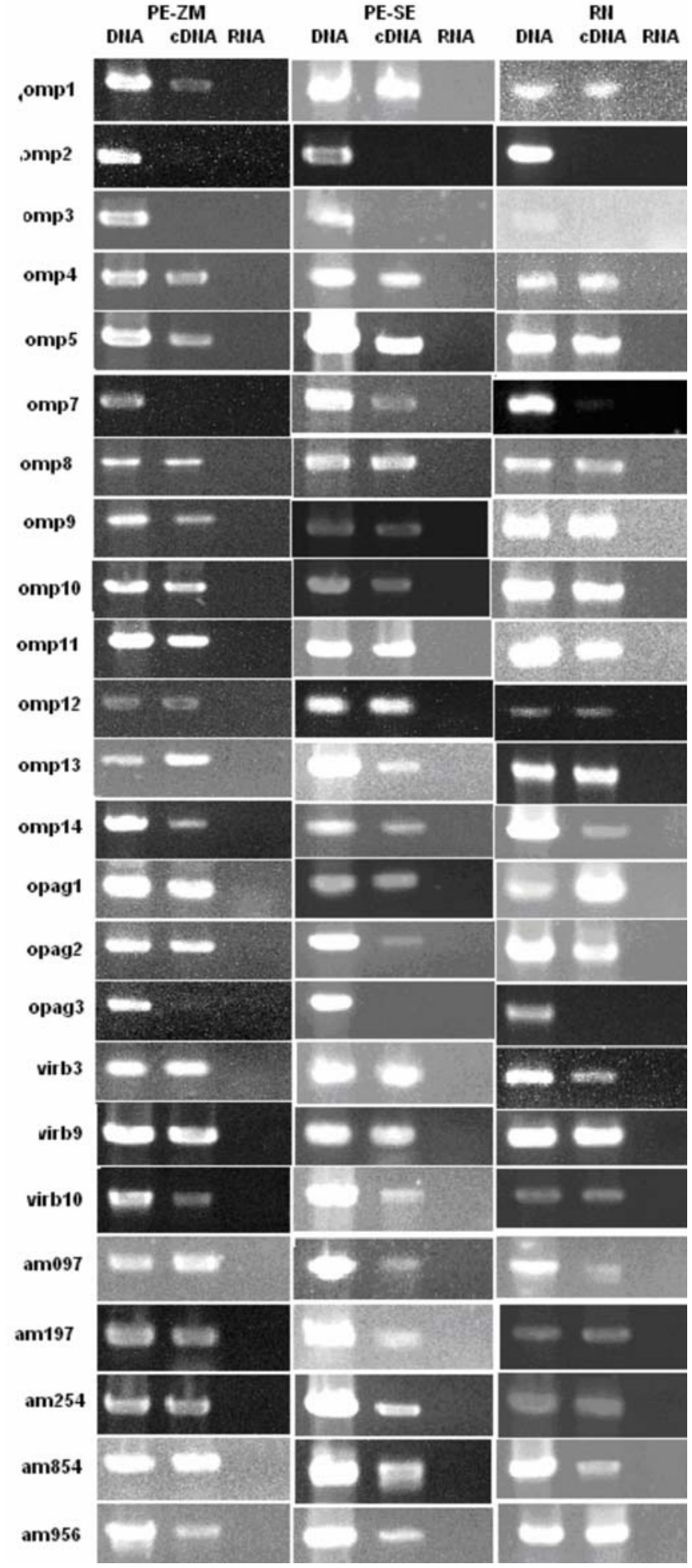

Figura 1. Detecção de transcritos de genes para proteínas de membrana de diferentes isolados brasileiros de Anaplasma marginale. $\mathrm{PE}-\mathrm{ZM}=$ Pernambuco - Zona da Mata; $\mathrm{PE}-\mathrm{SE}=$ Pernambuco - Sertão, RN = Rio Grande do Norte.

renças no padrão de transcrição entre os isolados americanos e os isolados brasileiros analisados, uma vez que, nos EUA, a transmissão biológica de A. marginale é realizada por carrapatos do gênero Dermacentor (KOCAN et al., 1981), enquanto 
no Brasil o carrapato Rhipicephalus (Boophilus) microplus é o responsável por esse tipo de transmissão (ALONSO et al., 2002).

\section{REFERÊNCIAS BIBLIOGRÁFICAS}

ALONSO, M.; ARRELANO-SOTA, C.; CERESER, V.H.; CORDOVES, C.O.; GUGLIELMONE, A.A.; KESSLER, R.; MANGOLD, A.J.; NARI, A.; PATARROYO, J.H.S.; SOLARI, M.A.; VEJA, C.A.; VIZCAÍNO, O.; CAMUS, E. Epidemiology of bovine anaplasmosis and babesiosis in Latin America and Caribbean. Revue Scientifique et Technique (International Office of Epizootics), v. 11, n. 3, p. 713-733, 1992.

ARAÚJO, F.R.; MELO, V.S.P.; RAMOS, C.A.N.; MADRUGA, C.R.; SOARES, C.O.; KESSLER, R.H.; ALMEIDA, N.F.; ARAÚJO, G.S.; ALVES, L.C.; TORRES JUNIOR, R.A.A.; FRAGOSO, S.P.; ARAUCO, P.R.C.; BACA-NELLI, G.; OLIVEIRA, M.B.; SANTOS, L.R. Development of enzyme-linked immunosorbent assays based on recombinant MSP1a and MSP2 of Anaplasma marginale. Memórias do Instituto Oswaldo Cruz, v. 100, n. 7, p. 765-769, 2005.

BATEMAN, A.; CORIN, L.; DURBIN, R.; FINN, R.D.; HOLLICH, V.; GRIFFITHS-JONES, S.; KHANNA.A.; MARSHALL, M.; MOXON, S.; SONNHAMMER, E.L.; STUDHOLME, D.J.; YEATS, C.; EDDY, S.R. The Pfam protein families database. Nucleic Acids Research, v. 32, supl. 1, p. 138-141, 2004.

BRAYTON, K.A.; KAPPMEYER, L.S.; HERNDON, D.R.; DARK, M.J.; TIBBALS, D.L.; PALMER, G.H.; McGUIRE, T.C.; KNOWLES, D.P. Complete genome sequencing of Anaplasma marginale reveals that the surface is skewed to two superfamilies of outer membrane proteins. Proceedings of the National Academy of Science USA, v. 102, n. 3, p. 844-849, 2005.

BRAYTON, K.A.; PALMER, G.H.; BROWN, W.C. Genomic and proteomic approaches to vaccine candidate identification for Anaplasma marginale. Expert Reviews Vaccines, v. 5, n. 1, p. 95-101, 2006.

BROWN, W. C.; SHKAP, V.; ZHU, D.; McGUIRE, T. C.; TUO, W.; McELWAIN, T. F.; PALMER, G. H. CD4 ${ }^{+}$Tlymphocyte and immunoglobulin G2 responses in calves immunized with Anaplasma marginale outer membranes and protected against homologous challenge. Infection and Immunity, v. 66, n. 11, p. 5406-5413, 1998a.

BROWN, W. C.; ZHU, D.; SHKAP, V.; McGUIRE, T. C.; BLOUIN, E. F.; KOCAN, K. M.; PALMER, G. H. The repertoire of Anaplasma marginale antigens recognized by CD4+ T-lymphocyte clones from protectively immunized cattle is diverse and includes major surface protein 2 (MSP-
2) and MSP-3. Infection and Immunity, v. 66, n. 11, p. 54145422, 1998b.

KOCAN, K. M.; HAIR, J. A.; EWING, S. A.; STRATTON, L. G. Transmission the Anaplasma marginale Theiler by Dermacentor andersoni Stiles and Dermacentor variabilis Say. American Journal of Veterinary Research, v. 42, n. 1, p. 15-18, 1981.

LÖHR, C. V.; BRAYTON, K. A.; SHKAP, V.; MOLAD, T.; BARBET, A. F.; BROWN, W. C.; PALMER, G. H. Expression of Anaplasma marginale major surface protein 2 operon-associated proteins during mammalian and arthropod infection. Infection and Immunity, v. 70, n. 11, p. 6005-6012, 2002.

LOPEZ, J. E.; SIEMS, W. F.; PALMER, G. H.; BRAYTON, K. A.; McGUIRE, T. C.; NORIMINE, J.; BROWN, W. C. Identification of novel antigenic proteins in a complex Anaplasma marginale outer membrane immunogen by mass spectrometry and genomic mapping. Infection and Immunity, v. 73, n. 12, p. 8109-8118, 2005.

McGUIRE, T. C.; MUSOKE, A. J.; KURTTI, T. Functional properties of bovine $\operatorname{IgG}_{1}$ and $\operatorname{IgG}_{2}$ : interaction with complement, macrophages, neutrophils and skin. Immunology, v. 38, n. 2, p. 249-256, 1979.

NOH, S. M.; BRAYTON, K. A.; KNOWLES, D. P.; AGNES, J. T.; DARK, M. J.; BROWN, W. C.; BASZLER, T. V.; PALMER, G. H. Differential expression and sequence conservation of the Anaplasma marginale msp2 gene superfamily outer membrane protein. Infection and Immunity, v. 74, n. 6, p. 3471-3479, 2006.

PALMER, G. H.; RURANGIRWA, F. R.; KOCAN, K. M.; BROWN, W. C. Molecular basis for vaccine development against the ehrlichial pathogen Anaplasma marginale. Parasitology Today, v. 15, n. 7, p. 281-286, 1999.

RIDING, G.; HOPE, M.; WALTISBUHL, D.; WILLADSEN, P. Identification of novel protective antigens from Anaplasma marginale. Vaccine, v. 21, n. 17-18, p. 1874-1883, 2003.

TEBELE, N.; MCGUIRE, T. C.; PALMER, G. H. Induction of protective immunity by using Anaplasma marginale initial body membranes. Infection and Immunity, v. 59, n. 9, p. 3199-3204, 1991.

VIDOTTO, M.C.; McGUIRE, T.C.; McELWAIN, T.F.; PALMER, G.H.; KNOWLES, D.P. Jr. Intermolecular relation-ships of major surface proteins of Anaplasma margi-nale. Infection and Immunity, v. 62, n. 7, p. 2940-2946, 1994.

ZAUGG, J. L. Bovine anaplasmosis: transplacental transmission as it relates to stage of gestation. American Journal of Veterinary Research, v. 46, n. 3, p. 570-572, 1985.

Recebido em 01 de março de 2007.

Aceito para publicação em 09 de julho de 2007. 